\title{
EXPLORE
}

\section{Sistem Pakar Diagnosis Hama Dan Penyakit Tanaman Kopi Menggunkan Metode Breadth First Search (BFS) Berbasis Web}

\author{
Favorisen R. Lumbanraja, Siti Rosdiana, Hamim Sudarsono, Akmal Junaidi \\ Jurusan Ilmu Komputer, Fakultas Matematika dan Ilmu Pengetahuan Alam \\ Jurusan Agroteknologi Fakultas Pertanian \\ Universitas Lampung \\ Bandar Lampung, Indonesia \\ favorisen.lumbanraja@fmipa.unila.ac.id,siti.rosdiana1505@students.unila.ac.id, \\ hamim.sudarsono@fp.unila.ac.idakmal.junaidi@fmipa.unila.ac.id
}

\begin{abstract}
Several factors cause low quality and productivity of coffee in Indonesia. Pests and diseases are considered as two of the main reason for these factors. Most coffee farmers in Indonesia, particularly in Province of Lampung are undereducated farmers. They still use traditional practices to identify pests and diseases. Using an expert system, we hope that farmers can accurately diagnose coffee pests and diseases. The main goal of this research is to develop a web-based expert system to diagnose coffee pests and diseases. To identify the pests and diseases Breadth First Search (BFS) technique was implemented. The data consist of 5 pests, 5 diseases, 28 symptoms of pest, and diseases the coffee plant. Certainty factor is used to weight the symptoms and it was determined by experts and the user. Then the certainty factor is iteratively computed the system to measure the likelihood of the diagnosis. To evaluate this system, 30 users were chosen and grouped into three clusters (the coffee experts, farmers, and agriculture students, computer science students). They were asked to assess this expert system by fulfilling questionnaires. They inferred that this system runs well with percentage respectively $75.56 \%, 73.78 \%$, and $83.39 \%$.
\end{abstract}

Keywords: Breadth First Search, Certainty Factor, Coffee, Expert System.

\begin{abstract}
Abstrak-Beberapa faktor menyebabkan rendahnya kualitas dan produktivitas kopi di Indonesia. Alasan utama permasalahan ini adalah gangguan hama dan penyakit. Sebagian besar petani kopi di Indonesia, khususnya di Provinsi Lampung adalah petani kopi yang tidak terdidik. Para petani masih menggunakan cara tradisional dalam mengidentifikasi hama dan penyakit. Dengan menggunakan sistem pakar diharapkan petani dapat melakukan diagnosis hama dan penyakit kopi secara akurat. Tujuan utama dari penelitian ini adalah membangun sistem pakar berbasis web untuk mendiagnosis hama dan penyakit tanaman kopi. Untuk mengidentifikasi hama dan penyakit tanaman kopi, teknik Breadth First Search digunakan. Data terdiri dari 5 hama, 5 penyakit, dan 28 gejala dari hama dan penyakit pada tanaman kopi. Certainty Factor digunakan untuk menentukan bobot setiap gejala dan nilainya ditentukan oleh pakar dan pengguna. Selanjutnya Certainty Factor secara iteratif dihitung oleh sistem untuk mengukur persentase hasil diagnosis. Untuk mengevaluasi sistem ini, 30 pengguna dipilih dan dikelompokkan menjadi 3 kelompok (pakar kopi, petani dan mahasiswa Fakultas Pertanian, mahasiswa jurusan Ilmu Komputer). Pengguna diminta untuk menilai sistem dengan mengisi kuesioner. Pengguna menyimpulkan bahwa sistem pakar berjalan dengan baik dengan persentase masing-masing $75.56 \%, 73,78 \%$ dan $83.39 \%$.
\end{abstract}

Kata Kunci: Breadth First Search, Certainty Factor, Kopi, Sistem Pakar

\section{Pendahuluan}

Indonesia merupakan negara produsen kopi terbesar yang menempati urutan ke-4 dunia [1], karena kopi merupakan salah satu hasil pertanian terbesar yang ada di Indonesia. Saat ini peningkatan produksi kopi di Indonesia terhambat oleh rendahnya produktivitas dan kualitas kopi yang dihasilkan. Salah satu penyebab rendahnya produktivitas dan kualitas kopi di Indonesia adalah adanya gangguan dari berbagai serangan hama dan penyakit [2].

Kurangnya informasi bagi petani kopi tentang jenis hama dan penyakit yang menyerang tanaman kopi menyebabkan banyak tanaman kopi tidak dapat ditangani dengan benar. Penanganan dan pengendalian secara baik dan benar menuntut para petani untuk bertindak cepat agar tanaman kopi dapat diselamatkan dari gangguan 
hama maupun serangan penyakit. Tujuan penelitian ini adalah memfasilitasi para petani daerah dalam mendiagnosis tanaman kopi terhadap gangguan dan serangan tersebut secara responsif. Petani kopi di daerah merupakan petani tradisional dimana banyak petani yang belum mengetahui bagaimana cara melakukan penanganan dan pengendalian terhadap hama maupun penyakit secara benar.

Di beberapa daerah masyarakat memilih profesi petani secara turun-temurun ataupun karena faktor kurangnya kesempatan kerja di bidang lain dan masyarakat yang masih terbatas pendidikannya. Para petani daerah biasanya melakukan penanganan dan pengendalian berdasarkan pengetahuan atau informasi yang diturunkan dari nenek moyang mereka maupun berdasarkan pengalaman yang dimiliki petani.

Saat ini infrastruktur jaringan internet maupun listrik sudah dapat dijangkau oleh hampir semua orang, sehingga masyarakat dari berbagai daerah dapat mengakses berbagai informasi dari media sosial ataupun laman situs yang banyak menyediakan informasi yang diperlukan. Dengan tersedianya infrastruktur yang memadai, petani tidak lagi mengalami kesulitan dalam mendapatkan berbagai pengetahuan dan informasi. Selain informasi dan pengetahuan yang harus dimiliki oleh petani tentang hama dan penyakit pada tanaman kopi, petani kopi juga membutuhkan suatu alat bantu yang dapat mengidentifikasi serangan hama dan penyakit pada tanaman kopi. Teknologi pada alat bantu tersebut dirancang agar dapat mengidentifikasi dan mengenali hama dan penyakit pada tanaman kopi. Teknologi yang cocok untuk keperluan ini adalah sistem pakar.

Suatu sistem pakar memerlukan teknik pencarian dalam menelusuri kemungkinan-kemungkinan solusi. Teknik pencarian ini umumnya bagian dari kelompok Uninformed Search atau Blind Search karena tidak ada informasi tambahan yang digunakan saat proses pencarian. Beberapa teknik ini antara lain Breadth First Search (BFS), Depth First Search (DFS), Depth Limited Search, Iterative Deepening Search (IDS), Uniform Cost Search (UCS), dan sebagainya. Sistem pakar ini mengintegrasikan metode Breadth First Search (BFS) dan metode Certainty Factor (CF). Metode Breadth First Search digunakan sebagai teknik pencarian solusi sedangkan metode Certainty Factor digunakan sebagai teknik pembobotan yang merepresentasikan faktor kepastian terhadap hama maupun penyakit berdasarkan gejala yang diberikan. Dalam penelitian ini dibangun suatu sistem pakar diagnosis hama dan penyakit pada tanaman kopi berbasis web.

\section{Metodologi}

\section{A. Data}

Data yang dibutuhkan pada penelitian ini berupa jenis-jenis hama, penyakit dan gejala serta deskripsinya. Data-data tersebut didapatkan dari buku "Musuh Alami, Hama, dan Penyakit Tanaman Kopi” [3], buku "Teknologi Pengendalian Hama dan Penyakit Tanaman Kopi" [4] dan sebuah database hama dan penyakit tanaman dari sebuah website departemen proteksi tanaman, Institut Pertanian Bogor (IPB) [5]. Data-data tersebut divalidasi oleh seorang pakar yang ahli hama dan penyakit tanaman.

\section{B. Pengumpulan Data}

Pengumpulan data dilakukan dengan menggunakan 2 metode, pengumpulan data dilakukan agar data tersebut dapat diolah sebelum proses pembutan sistem:

\section{Studi pustaka}

Pengumpulan data dilakukan dengan mencari berbagai literatur seperti buku, jurnal, penelusuran media internet ataupun dokumen yang berkaitan dengan tema penelitian.

\section{Wawancara}

Pengumpulan data dilakukan dengan cara wawancara atau berkonsultasi langsung dengan Prof. Dr. Ir. Hamim Sudarsono, M.Sc seorang ahli/pakar hama dan penyakit tanaman kopi dan juga menjabat sebagai guru besar Universitas Lampung dalam bidang hama tanaman. Hal ini dilakukan bertujuan untuk mendapatkan data-data yang valid, selanjutnya data-data yang telah dikumpulkan disusun menjadi basis aturan yang akan digunakan dalam sistem pakar.

\section{Pra-Prosess}

Sebelum melakukan proses pembuatan sistem data yang sudah didapatkan diolah menjadi sebuah tabel keputusan dimana tabel keputusan merupakan tabel yang berisi relasi atau hubungan antara hama dan penyakit dengan masing-masing gejalanya. Setelah tabel keputusan dibentuk tahap selanjutnya adalah membuat sebuah pohon keputusan untuk mempermudah proses penelusuran/pencarian hama dan penyakit. Representasi pengetahuan yang digunakan yaitu kaidah produksi, yang dituliskan dalam bentuk pernyataan jika-maka (if-then). Representasi pengetahuan dibuat berdasarkan data hama, penyakit dan gejalanya, representasi pengetahuan dibangun berdasarkan tabel keputusan yang kemudian dibentuk kedalam sebuah aturan, pada sistem pakar hama dan penyakit pada tanaman kopi terdapat 10 aturan yang nantinya akan diterapan pada proses pengkodean program.

\section{Metode}

Sistem pakar yang dikembangkan dalam penelitian ini adalah sistem berbasis web. Proses searching yang diaplikasikan pada sistem pakar ini merujuk pada pendekatan BFS sedangkan pembobotan faktor-faktor atau gejala-gejala hama dan penyakit menggunakan konsep CF. Masing-masing pendekatan ini diuraikan berikut ini.

\section{Breadth First Search}

Breadth First Search (BFS) adalah algoritma yang melakukan pencarian secara top-down dari simpul akar hingga ke semua simpul lainnya [6]. Pencarian dimulai dari node root sebagai komponen frontier (komponen rute penyelesaian) lalu memperluas frontier tersebut dari simpul akar hingga ke simpul akhir yang berada pada level bawah. BFS Algorithm akan mengunjungi simpul tetangga langsung pada level $\mathrm{n}$ terlebih dahulu sebelum mengunjungi simpul pada level $n+1$ [7]. Pada sistem ini, BFS digunakan dalam proses penelusuran/pencarian solusi.

Gambar proses pencarian BFS Algorithm dapat dilihat pada Gambar 1: 


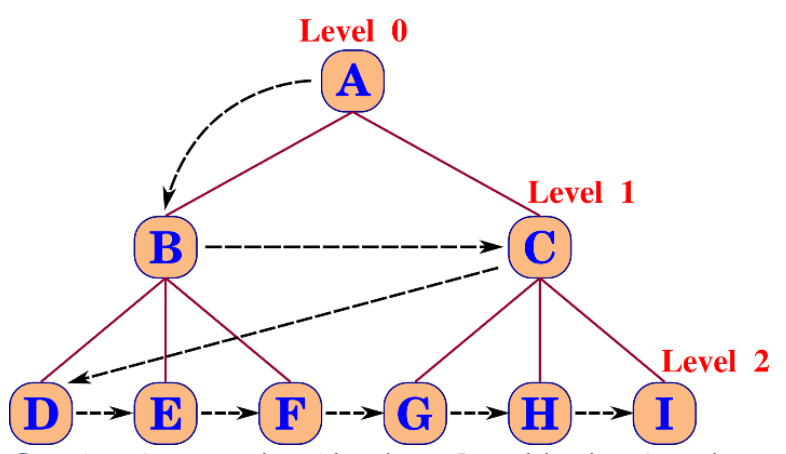

Gambar 1. Pencarian Algoritme Breadth First Search [8]

\section{Certainty Factor}

Certainty factor (CF) digunakan sebagai metode pembobotan pada setiap gejala yang dimiliki oleh hama maupun penyakit. Konsep CF digunakan pertama kali dalam bidang medis untuk mereprentasikan ketidakpastian pemikiran (inexact reasoning) seorang pakar [9]. Seorang pakar sering menganalisis informasi yang diberikan dengan ungkapan seperti "mungkin", "kemungkinan besar" atau "hampir pasti" [10]. Jenis nilai certainty factor dapat dikelompokkan menjadi 2 [11] yaitu:

1) Nilai CF kaidah yang nilainya melekat pada suatu kaidah/rule tertentu dan besarnya nilai diberikan oleh pakar.

2) Nilai CF yang diberikan oleh pengguna untuk mewakili derajat kepastian/keyakinan atau premis (misalnya gejala, kondisi, ciri) yang dialami pengguna.

Kombinasi Certainty Factor yang digunakan untuk sistem pakar yaitu:

1) Certainty Factor untuk kaidah dengan premis/gejala tunggal (single premis rule):

$$
\mathrm{CF} \text { gejala }=\mathrm{CF}[\text { user }] \times \mathrm{CF}[\text { pakar }]
$$

2) Apabila terdapat kaidah dengan kesimpulan yang serupa (similiary concluded rules) atau lebih dari satu gejala, maka CF selanjutnya dihitung dengan persamaan:

$\mathrm{CF}$ combine $=\mathrm{CF}$ old $+\mathrm{CF}$ gejala $\times(1-\mathrm{CF}$ old $)(2)$

3) Sedangkan untuk menghitung persentase terhadap hama/penyakit, digunakan persamaan:

$$
\text { CF persentase }=\mathrm{CF} \text { combine } \times 100 \%
$$

Untuk menentukan faktor keyakinan dari seorang pakar, salah satu pedoman kuantitatif dalam memberikan interpretasi (term) dapat dilihat pada Tabel 1. Dalam pedoman ini, disajikan nilai CF dari derajat yang paling tidak mungkin hingga ke derajat yang paling pasti. Derajat yang tidak pasti diberi nilai negatif sedangkan derajat yang paling pasti diberi nilai 1 (satu)

Tabel 1 Interpretasi Certainty Factor

\begin{tabular}{lc}
\hline \multicolumn{1}{c}{ Uncertain Term } & CF \\
\hline Pasti tidak & -1.0 \\
Hampir pasti tidak & -0.8 \\
Kemungkinan besar tidak & -0.6 \\
Mungkin tidak & -0.4 \\
Tidak tahu & -0.2 to 0.2 \\
Mungkin & 0.4 \\
Kemungkinan besar & 0.6 \\
Hampir pasti & 0.8 \\
Pasti & 1.0 \\
\hline
\end{tabular}

\section{Hasil dan Pembahasan}

Analisis koleksi data-data dan wawancara menghasilkan informasi 5 jenis hama dan 5 jenis penyakit dengan 28 gejala. Untuk data hama diberi kode " $H$ ", dan data penyakit diberi kode "P", sedangkan data gejala diberi kode "G".

Tabel 2 menampilkan daftar kode dan nama hama tanaman kopi. Dalam tabel ini terdapat 5 hama tanaman kopi yang diimplementasikan dalam sistem pakar ini. Hama-hama ini merupakan organisme hewan yang telah teridentifikasi sebagai penggangu tanaman kopi.
Penjelasan singkat masing-masing hama ini diuraikan sebagai berikut.

Tabel 2 Data Hama Tanaman Kopi

\begin{tabular}{ll}
\hline Kode & Nama Hama \\
\hline H1 & Penggerek Buah Kopi \\
H2 & Penggerek Cabang Kopi \\
H3 & Penggerek Batang \\
H4 & Kutu Hijau \\
H5 & Kutu Putih \\
\hline
\end{tabular}


1. Penggerek Buah Kopi (PBKo)

Serangan pertama hama PBKo adalah pada bagian kebun yang saling bernaungan. Serangan ini biasanya terjadi pada kebun yang lembab dan perbatasan kebun. Serangan dari hama ini akan menyebar ke seluruh kebun jika tidak segera dikendalikan. Hama PBKo atau Hypothenemus hampei akan sangat merugikan petani karena hama ini mampu merusak biji kopi dan populasi dari hama ini dapat dikatakan sangat tinggi.

2. Penggerek Cabang Kopi

Penggerek cabang kopi disebabkan oleh kumbang kecil yang dikelompokkan ke dalam golongan serangga. Kumbang ini hidup terbatas di daerah panas dan daerah tropis. Walaupun hama ini memiliki hidup terbatas, hama ini dapat dikatakan hama penting karena dapat beradaptasi dengan lingkungannya [3]. Xylosandrus spp atau lebih dikenal hama penggerek cabang kopi lebih sering menyerang cabang ranting tua dan sakit. Cabang atau ranting kopi yang tidak berbuah adalah karena adanya gangguan dari kumbang ini, yang biasanya membuat lubang pada ranting pohon kopi kemudian kumbang tersebut hidup dalam lubang tersebut [3].

3. Penggerek Batang

Penggrek batang atau biasa disebut zuzera coffee adalah ngengat yang bermetamorfosa sempurna. Serangga ini dapat bertahan hidup berbulan-bulan pada batang kopi. Saat ngengat betina meletakan telurnya dipermukaan batang kopi, kemudian menetas maka hama tersebut akan langsung menggerek bagian atas pada batang kopi [4]. Serangan hama ini dapat diatasi dengan cara menutup lubang gerekan dan ulat yang ditemukan segera dimusnahkan dengan cara dibakar.

4. Kutu Hijau

Cocus viridis atau kutu hijau adalah serangga yang fase hidupnya tetap tinggal di satu tempat untuk menghisap cairan dari tanaman. Kutu hijau tinggal dipermukaan bawah daun, terutama tinggal pada bagian tulang daun dan biasanya kutu hijau hidup bergerombol. Daun yang terserang hama kutu hijau akan ditumbuhi jamur embun jelaga berwarna hitam. Kutu hijau lebih suka musim kemarau dan juga lebih senang di dataran rendah dari pada di dataran tinggi [4].

5. Kutu Putih

Kutu putih memiliki mulut seperti jarum yang berfungsi untuk menghisap cairan dari tanaman. Kutu putih atau ferrisi virgata merupakan hama yang merusak daun kopi karena jamur yang hasilkan oleh kutu putih akan menhambat tanaman kopi dalam proses fotosintesis. Jamur yang disebabkan kutu putih biasanya berwarna hitam [3].

Tabel 3 berikut ini merupakan daftar kode dan nama penyakit yang dapat menyerang tanaman kopi dan diberi kode "P". Total jumlah penyakit yang ditangani dalam sistem pakar ini berjumlah 5 penyakit. Penyakit-penyakit ini dipicu oleh berbagai penyebab seperti faktor lingkungan, tumbuhan penggangu atau tumbuhan parasit.
Karakteristik masing-masing penyakit ini dijelaskan pada bagian selanjutnya.

Tabel 3 Data Penyakit Tanaman Kopi

\begin{tabular}{ll}
\hline Kode & Nama Penyakit \\
\hline P1 & Karat Daun Kopi \\
P2 & Bercak Daun Kopi \\
P3 & Nemotoda \\
P4 & Jamur Upas \\
P5 & Penyakit Akar \\
\hline
\end{tabular}

\section{Karat Daun Kopi}

Tanaman kopi terserang penyakit karat daun kopi mulai dari proses pembibitan sampai tanaman dewasa. Penyakit karat daun kopi disebabkan oleh adanya jamur H. Vastatrix. Salah satu penyebab terjadinya penyakit karat daun kopi karena dipengaruhi oleh faktor kelembaban [3].

\section{Bercak Daun Kop}

Kurangnya pemeliharaan kebun dan keadaan lingkungan yang lembab serta karena pola tanam yang kurang baik menyebabkan penyebaran penyakit bercak daun ini. Jamur C. Coffeicola merupakan jamur yang menyebabkan tanaman kopi terserang penyakit ini [4].

\section{Nematoda}

Nematoda terkenal sebagai organisme pengganggu tanaman (OPT) yang sangat merugikan tanaman kopi. Tanaman kopi yang terserang nematoda akan mengalami gangguan saat proses fotosintesis dan transpirasi. Akibatnya proses pertumbuhan tanaman kopi akan terganggu oleh penyakit yang disebabkan nematoda [4]. Ada 2 jenis nematoda yang menyerang tanaman kopi yaitu Pratylenchus Coffeae dan Radopholus Similis adalah yang merupakan sejenis Nematoda Endoparasit yang selalu berpindah-pindah [3].

4. Jamur Upas

Jamur upas merupakan penyakit yang memiliki arti cukup penting dalam budidaya kopi karena jamur upas dapat menyerang hampir seluruh bagian tanaman kopi mulai dari batang, ranting, buah kopi sampai ke cabang kopi [4]. Penyakit jamur upas biasanya disebabkan oleh jamur C. Salmonicolor yang tersebar luas di daerah tropika. Penyebaran jamur ini melalui tiupan angin atau percikan air, keadaan lembab dan kurangnya sinar matahari [3].

5. Penyakit Akar

Penyakit akar merupakan penyakit yang disebabkan oleh adanya jamur C. Salmonicolor yang dapat menyerang seluruh bagian tanaman kopi. Penyakit akar ini disebabkan oleh jamur C. Salmonicolor yang menyerang akar tanaman kopi karena faktor kelembaban dan kurangnya sinar matahari.

Dari 5 hama dan 5 penyakit tanaman kopi tersebut, dapat diidentifikasi gejala tanaman terserang hama atau penyakit sebanyak 28 gejala. Masing-masing gejala tersebut diberi kode "G" dan disajikan pada Tabel 4 berikut:

Tabel 4 Data Gejala Penyakit atau Tanaman Kopi

\begin{tabular}{cl}
\hline Kode & \multicolumn{1}{c}{ Gejala } \\
\hline G1 & Buah Tidak Berkembang \\
G2 & Warna Buah kopi berubah menjadi kuning kemerahan
\end{tabular}




$\begin{array}{ll}\text { G3 } & \text { Biji Kopi Berlubang } \\ \text { G4 } & \text { Cabang / ranting tanaman mongering } \\ \text { G5 } & \text { Daun layu } \\ \text { G6 } & \text { Daun Gugur } \\ \text { G7 } & \text { Terdapat lubang masuk larva } \\ \text { G8 } & \text { Adanya jamur embun jelaga } \\ \text { G9 } & \text { Daun menguning } \\ \text { G10 } & \text { Daun mengering } \\ \text { G11 } & \text { Adanya jamur berwarna hitam } \\ \text { G12 } & \text { Adanya bercak kuning jingga } \\ \text { G13 } & \text { Timbul bercak kuning kemudian coklat } \\ \text { G14 } & \text { Daun timbul bercak kuning dikelilingi lingkaran kuning } \\ \text { G15 } & \text { Kulit Buah mengering dan keras } \\ \text { G16 } & \text { Daun berwarna coklat } \\ \text { G17 } & \text { Pertumbuhan tanaman terhambat atau kerdil } \\ \text { G18 } & \text { Cabang-cabang samping tidak tumbuh } \\ \text { G19 } & \text { Tanaman layu mendadak } \\ \text { G20 } & \text { Adanya benang benang jamur tipis } \\ \text { G21 } & \text { Adanya bintil-bintil kecil berwarna orange kemerahan } \\ & \text { pada kayu } \\ \text { G22 } & \text { Tampak miselium } \\ \text { G23 } & \text { Akar berubah warna menjadi kuning gading } \\ \text { G24 } & \text { Akar tertutup oleh kerak } \\ \text { G25 } & \text { Terjadi busuk kering dan lunak } \\ \text { G26 } & \text { Pohon mati secara mendadak } \\ \text { G27 } & \text { Terdapat banyak benang jamur berwarna hitam } \\ \text { G28 } & \text { Pusat lingkaran bercak berwarna putih kelabu ada } \\ & \text { seperti tepung hitam (konidium jamur) } \\ & \end{array}$

seperti tepung hitam (konidium jamur)

Tabel 4 ini merupakan hasil ekstraksi data hasil observasi dari buku-buku referensi [3] [4] dan database hama dan penyakit tanaman Departemen Proteksi Tanaman IPB [5]. Gejala-gejala yang tercantum pada tabel merupakan tanda yang dapat diidentifikasi secara visual pada tanaman kopi. Tanda-tanda yang tidak dapat diamati secara fisik pada tanaman kopi bukan bagian dari kajian penelitian ini sehingga belum dapat diproses pada sistem pakar hasil penelitian ini.

\section{A. Penerapan Certainty Factor}

Teknik perhitungan/pembobotan yang digunakan dalam penelitian ini yaitu menggunakan metode certainty factor, dalam perhitungan nilai kepastian (certainty factor) digunakan nilai kepercayaan pakar dan kepercayaan user. Untuk nilai kepercayaan pakar diperoleh langsung dari seorang pakar, dimana masing-masing hama atau penyakit memiliki nilai kepercayaan yang berbeda, nilai kepercayaan user didapatkan dari jawaban user dimana jawaban "ya" diberi bobot 1, jawaban "ragu-ragu" diberi bobot 0.5 dan "tidak" diberikan bobot 0 . Sebagai contoh, pengguna melakukan diagnosis mengenai hama dengan beberapa gejala sebagai berikut:

1. Buah tidak berkembang (G1)

2. Warna buah kopi berubah menjadi kuning kemerahan (G2)

3. Biji kopi berlubang (G3)
Gejala-gejala yang terpilih merupakan salah satu rule dari representasi pengetahuan yang dibuat:

Rule 1.

IF Buah tidak berkembang (G1)

AND Warna buah kopi berubah menjadi kuning kemerahan $(\mathrm{G} 2)$

AND Biji Kopi Berlubang (G3)

THEN Penggerek Buah Kopi (H1)

Masing-masing gejala tersebut memiliki nilai CF yang sudah ditentukan oleh pakar dimana:

1. Buah tidak berkembang $($ Cfpakar $=0.6)$

2. Warna buah kopi berubah menjadi kuning kemerahan (Cfpakar $=0.6)$

3. Biji kopi berlubang $($ Cfpakar $=1.0)$

Misalkan pengguna memilih jawaban sebagai berikut:

1. Buah tidak berkembang "Ya" (Cfuser $=1)$

2. Warna buah kopi berubah menjadi kuning kemerahan "Ya" (Cfuser = 1)

3. Biji kopi berlubang "Ya" (Cfuser = 1)

Setiap gejala yang dipilih oleh pengguna dihitung nilai kepastiannya dengan Persamaan 1 dimana CFuser $x$ CFpakar: 


$$
\begin{aligned}
& C F 1=1 \times 0.6=0.6 \\
& C F 2=1 \times 0.6=0.6 \\
& C F 3=1 \times 1.0=1.0
\end{aligned}
$$

Kemudian kombinasikan hasil nilai CF pengguna yang sudah dikalikan dengan CF pakar dengan Persamaan 2:

$$
\begin{aligned}
\text { CF combine } & =C F 1+C F 2 \times(1-C F 1) \\
& =0.6+0.6 \times(1-0.6) \\
& =0.84=\text { CFold } \\
\text { CF combine } & =\text { CFold }+ \text { CF } 3 \times(1-\text { CFold }) \\
& =0.84+1.0 \times(1-0.84) \\
& =1
\end{aligned}
$$

Selanjutnya untuk mendapatkan persentase keyakinan untuk diagnosis pada H1 digunakan Persamaan 3.

$$
\begin{aligned}
\text { CF persentase } & =\text { CF combine } \times 100 \% \\
& =1 \times 100 \% \\
& =100 \%
\end{aligned}
$$

Berdasarkan contoh tersebut, diperoleh kesimpulan bahwa diagnosis berdasarkan gejala yang telah dipilih oleh pengguna bahwa tanaman kopi terserang Hama Penggerek Buah Kopi (PBKo) dengan tingkat keyakinan $100 \%$.

\section{B. Penerapan Breadth First Search}

Teknik pencarian merupakan proses penelusuran yang digunakan untuk mencapai tujuan atau solusi. Teknik ini divisualisasikan dalam suatu struktur berbentuk tree. Struktur tree merupakan suatu representasi data yang secara bentuk menyerupai sebuah pohon yang terdiri dari serangkaian node (simpul) yang saling berhubungan. Node yang memiliki node anak disebut node induk (parent), sementara node anak hanya memiliki satu node induk.

Dalam menerapkan metode BFS, tree yang merepresentasikan alur keputusan digunakan untuk mempermudah proses pencarian/penelusuran solusi. Sistem pakar hama dan penyakit ini memerlukan dua pohon keputusan yaitu pohon keputusan hama dan pohon keputusan penyakit. Pohon keputusan untuk hama tanaman kopi memiliki 5 level dan ada 5 goal node yang harus dicari yaitu $\mathrm{H} 1, \mathrm{H} 2, \mathrm{H} 3, \mathrm{H} 4$ dan $\mathrm{H} 5$. Untuk mendapakatkan goal node $\mathrm{H} 1$ maka node yang harus ditelusuri adalah G1, G2, G3. Untuk mendapatkan goal node $\mathrm{H} 2$ maka node yang harus ditelusuri adalah G1, G2, G3, G4. Untuk mendapatkan goal node H3 maka node yang harus ditelusuri adalah G1, G2, G3, G4, G5, G6, G7. Untuk mendapatkan goal node $\mathrm{H} 4$ maka node yang harus ditelusuri adalah G1, G2, G3, G4, G5, G6, G7, G10, G9, G8. Untuk mendapatkan goal node $\mathrm{H} 5$ maka node yang harus ditelusuri adalah G1, G2, G3, G4, G5, G6, G7, G10, G9 G8, G11. Proses penelusuran/pencarian goal node dari setiap hama kopi dapat dilihat pada Tabel 5

Tabel 5 Proses Penelusuran Pohon Keputusan Hama Kopi

\begin{tabular}{ll}
\hline \multicolumn{1}{c}{ Proses Penelusuran } & Goal Node \\
\hline G1, G2, G3 & H1 \\
G1, G2, G3, G4 & H2 \\
G1, G2, G3, G4, G5, G6, G7 & H3 \\
G1, G2, G3, G4, G5, G6, G7, G10, G9, G8 & H4 \\
G1, G2, G3, G4, G5, G6, G7, G10, G9, G8, G11 & H5
\end{tabular}

Gambar 2 berikut ini merupakan contoh pencarian/penelusuran menggunakan BFS pada pohon keputusan hama tanaman kopi. Gejala-gejala yang berhasil diidentifikasi adalah buah tidak berkembang (G1), warna buah kopi berubah menjadi kuning kemerahan (G2), cabang/ranting tanaman mengering (G4) dan terdapat lubang masuk larva (G7). Proses penentuan hasil pencarian ditunjukkan oleh anak panah biru pada Gambar 2.

Proses awal pencarian dimulai dari root node G1 dan node $\mathrm{G} 1$ sesuai dengan gejala yang sedang dicari sehingga node G1 disimpan dalam memory sistem. Selanjutnya, proses pencarian akan turun satu level dan menelusuri node G2. Gejala G2 ternyata sesuai gejala yang sedang dicari sehingga proses mencatat node G2 ke dalam memory sistem. Pencarian selanjutnya menuju ke node tetangga yaitu G3. Gejala pada node G3 tidak sesuai dengan gejala yang sedang dicari. Karena semua gejala pada level ini telah ditelusuri, proses pencarian dilanjutkan ke level di bawahnya.

Gejala pertama pada pada level berikutnya adalah node G4. Gejala pada node G4 ini sesuai dengan gejala yang sedang dicari sehingga dicatat di dalam memory sistem. Selanjutnya proses pencarian bergeser ke node G5 yang bertetangga langsung dengan G4. Namun gejala pada G5 tidak sesuai dengan gejala yang sedang dicari sehingga proses bergeser lagi ke tetangga G6. Gejala pada node G6 juga tidak sesuai dengan gejala yang sedang dicari dan tidak ada lagi tetangga pada level yang sama sehingga proses dilanjutkan ke level di bawahnya.

Pada level ini, node $\mathrm{H} 2$ merupakan salah satu goal node yang segaris dengan gejala-gejala yang terekam di memory sistem. Namun, masih ada satu gejala yang harus dicari yaitu G7. Proses pencarian dilakukan kembali ke tetangga 
terdekat pada level yang sama. Node yang ditemukan adalah node G7. Gejala yang ada pada node G7 ini merupakan gejala terakhir yang sedang dicari. Oleh karena itu node G7 direkam pada memory sistem, dan selanjutnya proses penelusuran dilanjutkan ke level bawah untuk mencari goal node. Ternyata goal node yang teridentifikasi adalah H3 yang berada pada level 4. Dengan demikian, sistem pakar mengidentifikasi hama yang menyerang berdasarkan gejala-gejala tersebut sebagai hama penggerek batang (H3). Setelah goal node ditemukan pencarian tidak dilanjutkan ke node berikutnya.

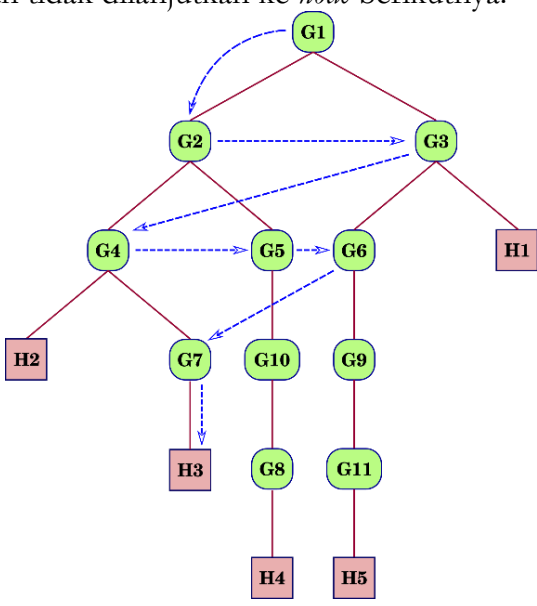

Gambar 2. Proses Penelusuran H3

\section{Analisis Kompleksitas BFS}

Proses penelusuran keputusan dengan pendekatan BFS ini tidak terlalu rumit. Kompleksitas waktu (time complexity) BFS tergantung langsung pada waktu yang dibutuhkan untuk menelusuri suatu node. Karena waktu yang dibutuhkan untuk menelusuri satu node memerlukan waktu konstan sehingga penelusuran node dengan BFS tergantung pada banyaknya node pada pohon keputusan. Dengan demikian kompleksitas waktu algoritma BFS memerlukan waktu linear atau $\mathrm{O}(\mathrm{n})$ dimana $\mathrm{n}$ adalah banyaknya node pada pohon keputusan.

Sedangkan kompleksitas ruang (space complexity) ditentukan dari seberapa banyak antrian node yang perlu ditempatkan dalam memory. Dalam kasus terburuk, semua titik pada pohon keputusan perlu ditempatkan dalam antrian untuk masuk dalam memory. Ini berarti ukuran antrian berkembang sebanyak node di dalam pohon keputusan. Dengan kata lain, kompleksitas ruang algoritma BFS juga memerlukan waktu linear atau $\mathrm{O}(\mathrm{n})$ dengan $\mathrm{n}$ menunjukkan jumlah node pada pohon keputusan. Dengan kompleksitas waktu dan ruang yang linear, sistem pakar ini dapat diinstalasi pada perangkat komputer dengan spesifikasi yang masih terjangkau oleh petani.

\section{Tampilan Sistem}

Tampilan awal sistem ini terdiri dari beberapa menu utama yang diletakkan pada sisi kiri. Menu-menu tersebut adalah Home, Hama dan Penyakit, Diagnosis, Bantuan dan Tentang. Berikut ini diuraikan isi menu yang merupakan bagian inti dari sistem ini.

\section{Halaman data hama atau data penyakit}

Halaman data hama merupakan halaman yang akan memberikan informasi hama dan penyakit tanaman kopi kepada pengguna. Dalam sistem pakar ini terdapat 5 jenis hama dan 5 jenis penyakit yang disertai gambar ilustrasi. Tampilan halaman data penyakit dapat dilihat pada Gambar 3
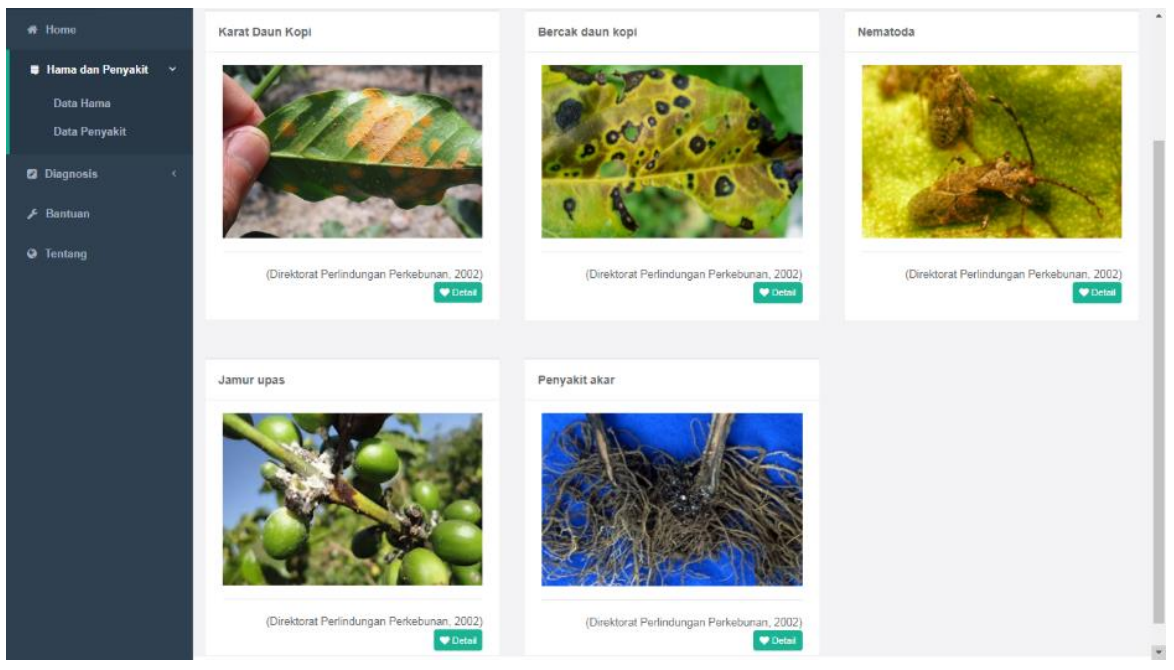

Gambar 3. Halaman data Penyakit

Gambar 3 menampilkan gambar penyakit-penyakit tanaman kopi yang ada pada sistem pakar ini. Untuk melihat informasi terperinci masing-masing penyakit tersebut, pengguna dapat mengklik tombol detail di bawah setiap gambar tersebut. Selanjutnya sistem pakar akan menampilkan informasi yang terkait dengan penyakit tersebut.

\section{Halaman Diagnosis}

Halaman diagnosis adalah halaman sistem pakar yang digunakan untuk diagnosis hama maupun penyakit tanaman kopi. Sub menu diagnosis terdiri dari diagnosis hama dan diagnosis penyakit. Pengguna yang ingin menggunakan sistem ini dapat memulai dengan pilihan ini. Contoh tampilan halaman diagnosis hama dapat dilihat pada Gambar 4. 

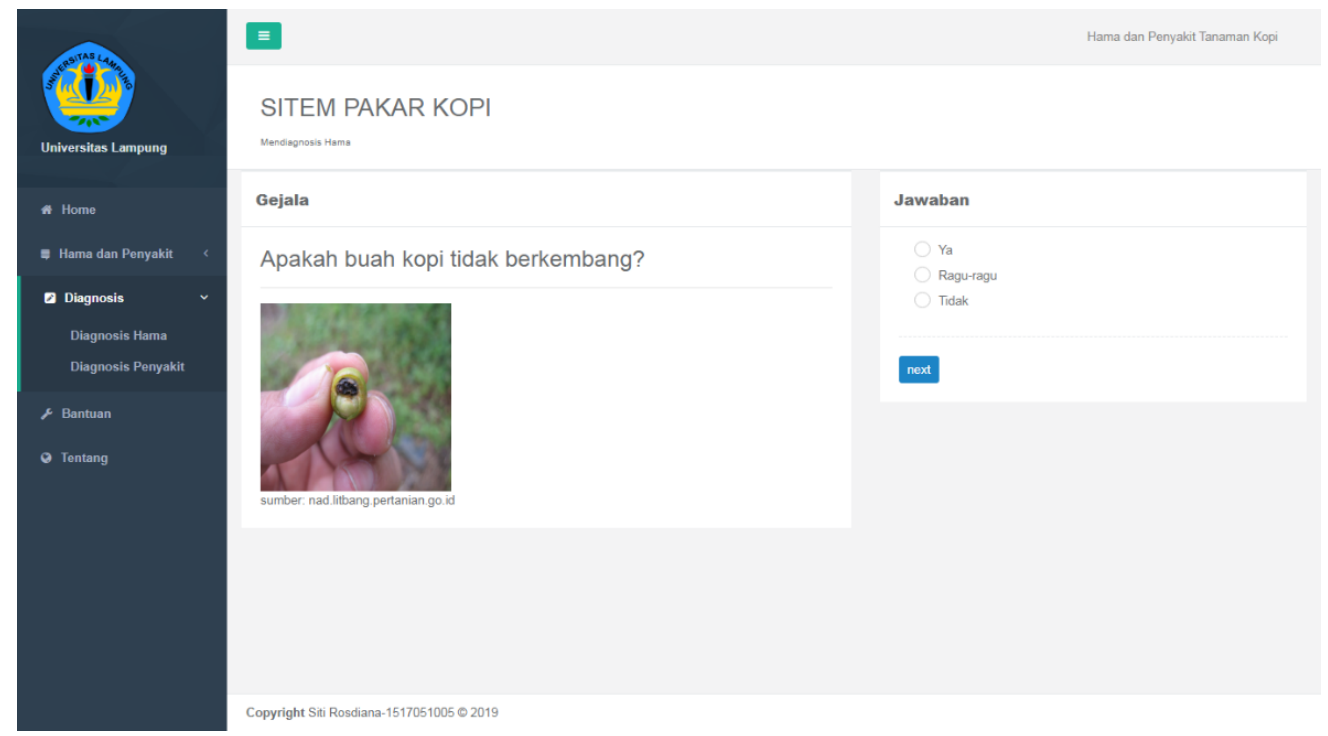

Gambar 4. Halaman Diagnosis Hama

Tampilan pada Gambar 4 terdiri dari 2 bagian yaitu bagian kiri dan kanan. Bagian kiri merupakan gejala yang akan ditanyakan oleh sistem. Obyek yang diperlihatkan pada gambar ini adalah satu sampel buah kopi yang tidak berkembang. Bagian kanan merupakan tempat pengguna memberikan jawaban atas pertanyaan tersebut. Jawaban dapat dipilih dengan mengklik radio button yang berada di depan alternatif jawaban. Selanjutnya pengguna dapat mengklik button next dan pertanyaan berikutnya akan muncul. Proses ini berlangsung beberapa kali sampai sistem menampilkan hasil halaman diagnosis. Secara internal, hasil diagnosis diperoleh melalui proses seperti yang ditunjukkan pada penjelasan Gambar 2. Contoh halaman hasil diagnosis ditunjukkan pada Gambar 5.
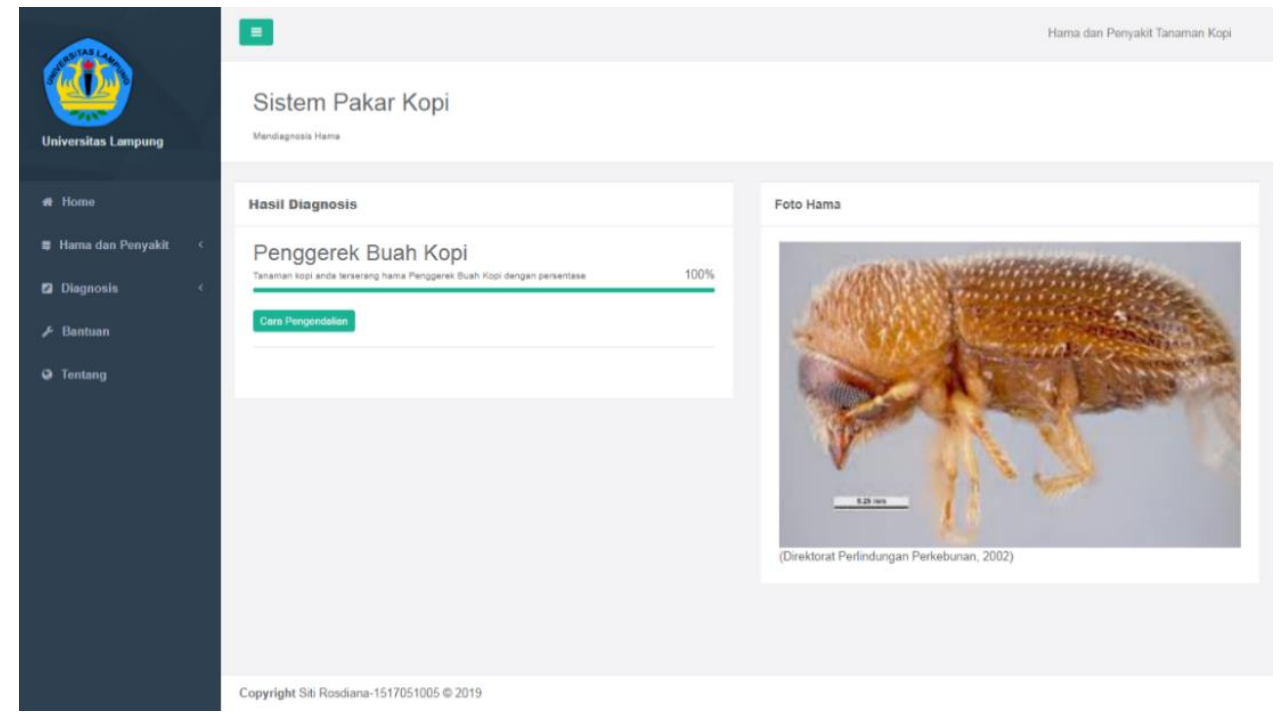

Gambar 5. Halaman Hasil diagnosis

Gambar hasil diagnosis terdiri dari nama hama/penyakit disertai gambarnya. Nama penyakit dicantumkan di bagian kiri sedangkan gambarnya berada di bagian kanan. Pada bagian bawah nama hama/penyakit terdapat link ke menuju halaman informasi cara penanggulangannya. Pengguna dapat menampilkannya dengan mengklik button cara penanggulangan.

\section{Evaluasi Sistem}

Sistem ini dikembangkan untuk membantu para petani kopi yang sulit mendapatkan akses terhadap kepakaran seorang ahli hama dan penyakit tanaman kopi.
Oleh karena itu sistem divalidasi dengan menyandingkan hasil diagnosis sistem dan hasil diagnosis pakar yang menjadi narasumber dalam sistem ini. Selain itu, sistem juga diujicobakan kepada beberapa responden pengguna yang dikelompokkan menjadi 3 kelompok. Berikut ini adalah hasil validasi sistem dan hasil ujicoba oleh pengguna.

\section{E. Validasi Hasil Diagnosis}

Validasi pakar bertujuan untuk menguji kemampuan sistem pakar dalam mengidentifikasi penyakit 
berdasarkan fakta-fakta yang dientry pada sistem. Hasil pengujian kepakaran hasil diagnosis sistem menunjukkan bahwa sistem ini dapat mendiagnosis hama dan penyakit dengan baik sesuai dengan hasil diagnosis yang dilakukan oleh pakar. Dari 10 diagnosis yang dihasilkan oleh sistem, tidak semua hasil diagnosis memiliki akurasi 100\% terhadap hama dan penyakit yang teridentifikasi. Namun demikian, hasil diagnosis telah menunjukkan tingkat keyakinan yang signifikan sehingga dapat dijadikan basis untuk penanggulangan gangguan hama dan penyakit.

\section{F. Penilaian Pengguna}

Penilaian pengguna diperoleh dari hasil penilaian jawaban kuesioner yang terdiri dari 9 pernyataan. Responden yang mengisi kuesioner dari 30 orang dikelompokkan menjadi 3 kelompok. Kelompok tersebut adalah responden 1 yang merupakan kelompok para pakar hama dan penyakit tanaman kopi. Responden 2 terdiri dari pengguna petani dan mahasiswa Fakultas Pertanian Universitas Lampung. Responden 3 adalah pengguna dari mahasiswa jurusan Ilmu Komputer Universitas Lampung. Hasil penilaian pengguna terhadap sistem pakar diukur berdasarkan kuesioner dengan 5 tingkat kepuasan masing-masing sangat setuju (SS), Setuju (S), Cukup Setuju (CS), Kurang Setuju (KS) dan Tidak Setuju (TS). Jawaban terhadap pernyataan-pernyataan kuesioner masing-masing responden 1 dan 2 didominasi oleh "setuju" sebanyak 75,56\% dan 73,78\%. Persentase ini masuk dalam interval 60,00\% - 79,99\% yang masuk kategori baik. Sedangkan penilaian responden 3 rata-rata menjawab pada tingkat Sangat Setuju (SS) dan Setuju (S) dengan rata-rata sebanyak $82,39 \%$. Persentase ini masuk dalam interval $80,00 \%-100,00 \%$ yang tergolong kategori sangat baik. Representasi hasil evaluasi responden ini mengindikasikan bahwa pengguna menilai sistem ini sudah baik dan hasil keluaran sistem dapat diterima dengan baik.

\section{Kesimpulan}

Dalam penelitian ini dapat disimpulkan bahwa metode Breadth First Search (BFS) dapat dijadikan sebagai teknik penelusuran untuk mencari solusi. Certainty factor (CF) dapat digunakan sebagai teknik pembobotan gejala dan perhitungan tingkat keyakinan. Sistem pakar ini dapat memberikan nilai keyakinan hasil diagnosis hama dan penyakit berdasarkan fakta dan pengetahuan yang dientry ke dalam sistem. Nilai tersebut dihitung menggunakan nilai CF dari seorang pakar dan CF dari pengguna itu sendiri. Selain dapat memberikan keputusan tentang hama atau penyakit kopi dari gejala-gejalanya, sistem ini juga menyediakan informasi cara pengendalian hama dan penyakit tersebut.

Sistem ini selanjutnya dievaluasi kinerjanya untuk menilai tingkat penerimaan pengguna. Berdasarkan evaluasi pengguna, proporsi ketiga kelompok responden masing-masing menyatakan setuju bahwa sistem pakar ini sudah baik meskipun persentase penilaiannya berbeda- beda. Dengan demikian, secara keseluruhan dapat disimpulkan bahwa penilaian pengguna terhadap sistem ini dikategorikan baik.

Meskipun sistem pakar ini telah berhasil diimplementasikan, terdapat beberapa peluang penelitian lanjutan, Peluang tersebut antara lain adalah penambahan fitur sistem untuk diagnosis dengan gambar tanaman yang terkena hama/penyakit. Dengan cara seperti ini, diagnosis dapat dilakukan dengan lebih teliti melalui observasi gambar yang diambil dengan kamera atau smartphone. Selain itu konsep machine learning dapat juga diaplikasikan untuk proses identifikasi dan klasifikasi hama dan penyakit tanaman kopi.

\section{Daftar Pustaka}

[1] Szenthe, “Top Coffee Producing Countries," World Atlas, 29 Mei 2019. [Online]. Available: https://www.worldatlas.com/articles/top-coffeeproducing-countries.html. [Diakses 30 September 2019].

[2] N. Firmansyah, A. Johar dan T. Prasetyo, "Sistem Pakar Identifikasi Pengecekan Kualitas Kopi Berbasis Web Dengan Menggunakan Metode Certainty Factor," Jurnal Rekursif, vol. 5, no. 3, pp. 298-306, 2017.

[3] Direktorat Perlindungan Perkebunan, Musuh Alami, Hama, dan Penyakit Tanaman Kopi, Jakarta: Departemen Pertanian, 2002.

[4] R. Harni, Samsudin, W. Amaria, G. Indriati, F. Soesanthy, Khaerati, E. Taufiq, A. M. Hasibuan dan A. D. Hapsari, Teknologi Pengendalian Hama dan Penyakit Tanaman Kopi, Jakarta: IAARD Press, 2015.

[5] D. P. Tanaman, "Basisdata Hama dan Penyakit Tanaman," Institut Pertanian Bogor, 2010. [Online]. Available: http://www.opete.info. [Diakses 19 Agustus 2019].

[6] K. Ueno, T. Suzumura, N. Maruyama, K. Fujisawa dan S. Matsuoka, "Efficient Breadth-First Search on Massively Parallel and Distributed-Memory Machines," Data Science and Engineering, vol. 2, no. 1, pp. 22-35, 2017.

[7] D. Zai, H. Budiati dan S. S. Berutu, "Simulasi Rute Terpendek Lokasi Pariwisata di Nias Dengan Menggunakan Metode Breadth First Search dan Tabu Search," Jurnal InFact, vol. 1, no. 2, pp. 30-41, 2016.

[8] E. Wijaya, "Analisis Penggunaan Algoritma Breadth First Search Dalam Konsep Artificial Intellegencia," Jurnal TIME, vol. II, no. 2, p. 18026, 2013.

[9] E. H. Shortliffe dan B. G. Buchanan, "A model of inexact reasoning in medicine," Mathematical Biosciences, vol. 23, pp. 351-379, 1975.

[10] T. Sutojo, E. Mulyanto dan V. Suhartono, Kecerdasan Buatan, Yogyakarta: Andi Offset, 2011.

[11] S. Hartati dan S. Iswanti, Sistem Pakar dan Pengembangannya, Yogyakarta: Graha Ilmu, 2008. 